\title{
A Cross-cultural Comparative Analysis of Views on Friendship in Chinese and English Idioms
}

\author{
Qian Zhang \\ Foreign Language Department, Baoding University, Hebei, China \\ Xiufeng Tian \\ Foreign Language Department, Hebei Finance University, Hebei, China
}

\begin{abstract}
Through the method of contrastive analysis, this thesis aims at presenting the differences as well as similarities between friendship view in China and that in English-speaking countries by examining Chinese and English idioms from the perspective of power distance, individualism versus collectivism and long-term versus short-term orientation. A further explanation of the characteristics of the two friendship views from the perspective of culture is also made.
\end{abstract}

Index Terms - friendship view, idiom, individualism versus collectivism, power distance, long-term versus short-term orientation

\section{INTRODUCTION}

Scholars from home and abroad have proposed plenty of theories about interpersonal relationship, which makes great contribution to cross-cultural communication and at the same time lays a solid foundation for the present study. The methods they adopt to formulate these theories mainly include questionnaire survey, collecting data in real life, doing follow-up survey, or case study, etc. Different from the previous research, this paper studies friendship, a main part of interpersonal relationship, by examining idioms that contain people's friendship views in English and Chinese languages.

Idiom is considered to be the treasure as well as carrier of national culture. Therefore, from Chinese and English idioms, we can get some knowledge of cultural discrepancy between China and the English-speaking countries. The culture of China and that of the English-speaking countries are different in geography, history, religious belief, custom of living, and so on. Therefore, the two cultures take on different views towards interpersonal relations. Based on this fact, this paper probes into the similarities and differences between the friendship views reflected in English and Chinese idioms. It is known that idioms are essences in a specific language, and cultural and historical traits are embedded in them. Therefore, through idioms about friendship in one language, we can get some knowledge of the friendship view in that culture. In this way, the author hopes to provide a better understanding of the two different friendship views from a perspective which has been rarely explored before.

\section{RESEARCh DESIGN}

\section{A. Theoretical Framework}

Power distance Hofstede defines power distance, the first of his cultural dimensions, as "the extent to which the less powerful members of institutions and organizations within a country expect and accept that power is distributed unequally." (Hofstede, 2001, 98)

According to Hofstede, the dimension of power distance deals with the need for dependence versus independence in society. High Power Distance cultures tend to be hierarchical, emphasizing dependence and conformity. Inequality is seen as the basis of social order. Seniors take a top down approach and tell juniors what to do. In cultures with high power distance, the less powerful accept power relations that are autocratic or paternalistic. Subordinates acknowledge the power of others based on their formal, hierarchical positions. Low Power Distance cultures tend to be egalitarian. People value independence and believe that distance between the powerful and the powerless should be minimized. In cultures with low power distance, people expect and accept power relations that are more consultative or democratic. People relate to one another more as equals regardless of formal positions. Subordinates possess the right to contribute to and criticize the decisions of those in power. Thus, Power Distance does not measure or attempt to measure a culture's objective power distribution, but rather the way people perceive power differences.

Individualism versus collectivism "Individualism-collectivism is the major dimension of cultural variability used to explain cross-cultural differences and similarities in communication across cultures" (Gudykunst, 1997, 56). Hofstede (2001) defines individualism as "the emotional independence of individual persons from groups, organizations, or other collectivities". Generally, it refers to the doctrine that each individual is unique, special, and completely different from 
all other individuals and "the basic unit of nature" (Stewart \& Bennert, 1991, 133). As Goleman points out, in individualist cultures, people's personal goals take priority over their allegiance to groups. The loyalty of individualists to a given group is very weak; they feel they belong to many groups and are apt to change their membership as it suits them.

Collectivism is characterized by a social framework that distinguishes between in-groups and out-groups. In collectivist cultures, "people count on their in-groups (relatives, clans, organizations) to look after them, and in exchange for that they believe they owe absolute loyalty to the group." (Samovar et al, 2000, 68) In individualistic cultures, people are supposed to look after themselves and their immediate family only, while in collectivistic cultures, people belong to in-groups or collectivities that are supposed to look after them in exchange for loyalty. "The attitudes to in-groups and out-groups are two important standards to decide whether this country or community belongs to individualistic culture or collectivistic culture." (Hofstede and Bond, 1984, 419) In individualist cultures, people are expected to develop and display their individual personalities and to choose their own affiliations. In collectivist cultures, people are defined and act mostly as a member of a long-term group, such as the family, a religious group and many others.

Long-term versus short-term orientation Hofstede's fifth dimension, long-term versus short-term orientation, is based on the study of Michael Bond which had noted that Hofstede's previous four cultural dimensions did not adequately reflect Asian perspectives of culture. As Hofstede notes, "Long Term Orientation (LTO) stands for the fostering of virtues oriented towards future rewards, in particular perseverance and thrift. It's opposite pole, Short Term Orientation, stands for the fostering of virtues related to the past and present, in particular, respect for tradition, preservation of 'face' and fulfilling social obligations." (Hofstede, 2001, 359)

According to Hofstede, long-term orientation, with its roots in the ethical imperatives of Confucianism, can be interpreted as dealing with a society's search for virtue. Long-term oriented cultures teach virtues directed at the future, such as education, frugality and persistence. Short-term oriented cultures teach virtues directed at the past and present, such as expectation for quick results, respect for traditions, social spending, and maintaining face.

\section{B. Methodology}

In order to systematically study friendship view embedded in Chinese and English idioms, the author uses contrastive analysis. Firstly, idioms about friendship in English and Chinese are collected from three dictionaries about Chinese idioms and three dictionaries about English idioms. Secondly, the collected idioms are classified according to three of Hofstede's cultural dimensions: power distance, individualism versus collectivism, and long-term versus short-term orientation. The third step is contrastive analysis. Under each cultural dimension, there are three parts, namely the English idioms about this dimension followed by analysis, the Chinese idioms about this dimension followed by analysis, and a contrast and comparison of the two analyses.

\section{DATAANALYSIS AND DisCUSSION}

\section{A. Power Distance}

Generally speaking, power distance measures the degree to which wealth, prestige and power are equally distributed in a culture, as well as how much equality versus inequality and dependence versus independence are desired.

\section{Analysis of Samples from English Idioms}

The following-listed idioms are the English idioms about power distance collected by the author:

1. A friend in court is better than a penny in purse

2. Friend at/in court

3. Have friends in high places

4. He that hath a full purse never wanted a friend. A rich person always has plenty of friends.

5. My honorable friend

6. My learned friend

7. Girl/Boy friend

8. Next friend

9. Man's best friend

10. Feathered friend

11. A friend of God

12. Big friend

From the English idioms listed above, it may be concluded that the friendship view embodied in English idioms has the following features:

a) People want to have friends that are powerful and influential so that they are able to depend on those friends to help them when it is needed. Besides, when expressing the idea that they have or want to have some influential friends, they express it with pride or even boast. This feature can be seen from such idioms as 1, 2, 3, and 4 .

b) It is common for people from similar background to make friends with one another. From 5 and 6 , it can be seen 
that in Britain, the congressmen in house of commons call each other friends and show respect by using "honorable". The same is true for lawyers in court by using "learned". Thus, it is proper to conclude that people with the same status or position can make friends with each other. Moreover, people of different sexes or statuses can be friends, such as boy/girl friend which has a special connotation that the two people have a romantic relationship. A next friend refers to the guardian of a minor. Thus, a minor is a friend of his guardian.

c) Man can make friends not only with man, but also with other creatures, God, or even objects. To dig it further, man are equal to all other things so that man can be friends with all of them. This feature is reflected in such idioms as 9 , 10, 11, and 12. From 9, it can be seen that man can make friends with dogs. Idiom 10, feathered friend expresses the idea that man can make friends with birds and other flocks. Idiom 11, a friend of God refers to the person who is very pious to God. So man can be friend of God. Idiom 12, big friends is an American slang which refers to bombers of our side.

\section{Analysis of Samples from Chinese Idioms}

The Chinese idioms about power distance collected by the author are listed as the follow:

1. gǒu zhàng rén shì

dog depend-on man power

be a bully under the protection of a powerful person

2. pān lóng fù fèng

climb dragon attach phoenix

to play up to or attach to people of power and influence

3. shìlì zhī jiāo, gǔ rén xiū zhī

power of relationship, ancient man shame that

Since ancient time, people have been ashamed of the friendship based on power.

4. fŭ shǒu tiē ěr

bow head droop ear

be docile and obedient

5. wéi mìng shì cóng

only order is obay

be absolutely obedient

6. lǐ xián xià shì

rite sage lower knowledgeable-person

to lower oneself to enlist the services of the talented and the learned

7. xū zuǒ yǐ dài

vacant honored-post to wait

to reserve the honored post for somebody competent

8. quăn mă zhī láo

dog horse of work

to serve like a dog or a horse

9. fù tāng dăo huǒ zài suǒ bù cí

go boiling-water tread fire in all not refuse

will never refuse, even one has to go through thick and thin

10. jūgōng jìn cuì š̌ érhòu yǐ

bow exhauste overworked die then stop

to devote oneself entirely to something until one's dying day

11. wàng nián zhī jiāo

forget age of relationship

friendship between young and old people or friendship between generations

From the above-listed idioms, several features of friendship view that is reflected in Chinese idioms are summarized as follow:

a) People should not be eager to make friends with influential and powerful people for interests or other material purposes. This idea is expressed in idioms like 13, 14 and 15. If people do make friends in high place and act flatteringly all the time, they will be looked down upon. For example, Chinese idioms 16 and 17 convey this notion.

b) It is advocated and praised if people with power and status are modest and respectful enough to make friends with lower-status people who are intelligent and wise. Such idioms as 18 and 19 show this point.

c) The author does not find any Chinese idiom that shows the friendship between people of different social statuses. More often than not, the relation between people of different status is a matter of boss and employees, host and servants, superior and subordinates. On the one hand, people of higher status should lower themselves so that they are able to treat lower-status people who are wise and intelligent respectfully, as the author has mentioned in II. On the other hand, the lower-status people should be loyal to their supervisor. They should also do their best to show their loyalty and repay their supervisor for his appreciation of their talent. This point is shown in idioms of 20, 21, and 22.

d) People of large age difference are not supposed to make friend with each other. However, the idiom 23 conveys the 
opposite meaning: friendship between old and young people or friendship between generations. It is proper to assume that generally people do not forget their age difference and make friends with one another.

Contrastive Analysis

In English idioms, powerful and influential friends are desirable and it is natural that people want to be friends with them for the purpose of prosperity, whereas in Chinese idioms, people are despised if they are eager to make friends with people in high place just for material purposes. According to Huang Guangguo (2004), the relationship in western countries tends to be instrumental, whereas the relationship in China is likely to be expressive. Therefore, Chinese people look down upon the friendship based on instrumental purpose, whereas in English countries it is a common phenomenon.

The English idioms reflect a phenomenon that it is common for people from different background, including social status, age, gender, etc, to make friends with each other. However, in Chinese idioms, this phenomenon is uncommon or even wrong. And the ordinary relation between people of different power is usually a matter of superior and subordinates. Jia (1997) points out that the power in China is associated with age, education, social class, sex, and family relation and so on. Confucianism in China requires people to behave according to their status, while in western countries equality is highly valued.

English idioms show that people can be friends with not only human being, but also other creatures and objects, which is rare in Chinese idioms. So we can infer that the equality in the west not only exists among human beings, but also among everything in the world, so that humans are friends with non-humans.

\section{B. Individualism versus Collectivism}

"In the individualist society, relationships with others are not obvious and prearranged; they are voluntary and have to be carefully fostered. In the collectivist society, one's friends are predetermined by one's group membership. This group membership is maintained through filial piety and loyalty, and is associated with patriotism." (Hofstede, 2001, 353)

\section{Analysis of Samples from English Idioms}

The following are the English idioms about individualism and collectivism collected by the author.

1. A friend in need is a friend indeed.

2. False friends are worse than open enemies

3. With friends like that, who needs enemies? To express the disapproval of the way in which someone's friends have behaved towards that person.

4. Fair-weather friend.

5. A friend to all is a friend to none/a friend to everybody is a friend to nobody.

6. The falling out of friends is the renewal of love.

7. Between friends all is common.

8. A hedge between keeps friendship green. Your friendship will flourish if you and your friend respect each other's privacy.

9. Lend your money and lose your friend. You should not lend money to your friends; if you do, either you will have to bother your friend to repay the loan, which will make your friend resent you, or your friend will not repay the loan, which will make you resent your friend.

10. Short accounts make long friends. If you borrow something from a friend, pay it back as soon as possible so that the two of you remain friendly.

11. Bosom friends; sworn friends; fast friends.

12. nodding friend

13. Birds of a feather flock together.

Having examined the English idioms listed above, the following characteristics of friendship can be summarized:

a) It is important to make a true friend or choose a right friend. Hardship can testify whether a friend is a true one, as is shown in 24. Besides, idioms 25 and 26 express the significance of making a right friend. In contrast, a fair-weather friend refers to someone who is friendly with you when you are enjoying good times, but who abandons you when you need help, which is much undesirable.

b) It does not matter whether a person has a large number of friends or not, what matters is the actual relationship between them. A person may have many friends, of which none is a close friend, as is shown in idiom 28 . In contrast, a person may have only a few friends, of which all are fast friends, as is shown in idiom 29.

c) Friends should share with each other. At the same time, they should also keep an arm's length with one another. This point is shown in idiom 30 and 31. However, one thing that friends should not share is money. Even if a person borrows money from his friends, he should return it quickly so as to maintain their friendship. This idea can be seen from idiom 32 and 33.

d) Friends can be divided into several types in terms of intimacy and closeness, such as idiom 34 and 35 .

e) People tend to make friends with whoever is similar to them, as is shown in 36.

Analysis of Samples from Chinese Idioms

The Chinese idioms about individualism versus collectivism are listed as follow: 
1. yīgè líba sāngè zhuāng, yīgè hăo hàn sāngè bāng. one fence three stake one good man three help

Even a strong man needs the help of his friends.

2. wèi péngyǒu liăng lèi chā dāo

for friend two rib stab knife

will do anything for friends

3. lĩ dài táo jiāng

plum substitute peach stiff

to sacrifice oneself for his friends

4. yǒu fú tóng xiăng yǒu nán tóng dāng

have happiness together enjoy have difficulty together bear

to share joys and sorrows; stick together through thick and thin

5. huànnàn jiàn zhēn qíng

hardship see true feeling

A friend in need is a friend indeed.

6. jūnž̌ zhī jiāo dàn rú shuǐ, xiăo rén zhī jiāo gān rú lǐ.

gentleman of relationship pure like water small man of relationship sweet like sweet wine

The friendship between gentlemen is pure like water, yet affectionate; the friendship between small men is sweet

like wine, yet easily broken.

7. zhì tóng dào hé

ideal same way close

to have a common goal or like-minded

8. gān dăn xiāng zhào

liver gallbladder mutual reflect

to treat each other with all sincerity

9. qiān lǐ sòng é máo,lǐ qīng qíngyì zhòng.

thousand li send goose feather gift light feeling heavy

The gift itself may be light as a goose feather, but sent afar, it conveys deep feeling.

10. xíng yǐng bù lí; qīnmì wú jiàn.

figure shadow not part intimate not crack

be very close and intimate with one another

11. jiāo rén jiāo xīn, jiāo huā jiāo gēn.

interact people interact heart water flower water root

Touch his heart when you make friends, and moisten roots when you water flowers.

12. hăinèi cún zhījīî, tiānyá ruò bì lín.

within-the-country exist bosom-friend long-distance seem compare neighbor

Bosom friends within the four seas are close neighbors though separated by great distance.

13. jìn zhū zhě chì, jìn mò zhě hēi.

close cinnabar people red close ink people black

One takes on the color of one's company; moral influence by contact of close association.

14. jĩ suǒ bù yù wù shī yú rén.

oneself the not want do-not apply to people

Do not do unto others what you do not want others to do unto you.

15. tuī jĩ jí rén

push oneself to people

to put oneself in another's position; to be considerate

16. yìzhě sān yǒu, yǒu zhí yǒu liàng yǒu duōwén.

beneficial three friends make-friend-with upright make-friend-with honest make-friend-with knowledgeable

Three kinds of friends are beneficial, that is, upright friend, honest friend, and knowledgeable friend.

17. yǔ péngyǒu jiāo, yán ér yǒu xìn.

with friend interact word then have credit

There should be trust and faithfulness between friends.

18. fànfàn zhī jiāo

general of relationship

casual acquaintance

19. bù jí bù lí

not close not distant

be neither too familiar nor too distant

20. nèi shū wài qīn 
inside distant outside intimate

be apparently intimate but actually indifferent

21. mò nì zhī jiāo

not against of relationship

friends with complete mutual understanding

22. wěn jǐng zhī jiāo

cut neck of relationship

a friendship that would lead persons to die for each other

23. qíng rú xiōngdì

feeling like brothers

be close like brothers

24. wù yǐ lèi jù rén yǐ qún fền

thing by class gather people by group divide

Birds of a feather flock together.

From the Chinese idioms listed above, it is reasonable to summarize that friendship view reflected in Chinese idioms has the following features:

a) The most important thing between friends is loyalty and faithfulness. People should be loyal to their friends under whatever circumstances. Therefore, mutual help matters a lot between friends regardless whether the help is right or not. This point is conveyed in idiom 37,38 , and 39.

b) Friends are those who can company one another through thick and thin, as is expressed in idiom 40 and 41 .

c)Friends should pay more attention to spiritual togetherness and emotional exchange rather than material things. This idea can be seen in idiom 42, 43, 44, and 45 .

d)Friends may show their closeness by physical intimacy, such as 46 , as well as by spiritual intimacy, such as 47 . When two friends are spiritually intimate, physical distance means nothing, as is shown in idiom 48 and 45.

e) The influence of friends on a person is significant, which is expressed in idiom 49.

f) There are some idioms that tell people how to treat their friends, emphasizing empathy, integrity between friends, or telling people what kind of friends are beneficial. This idea can be seen from idiom 50, 51, 52, and 53.

g)There are several kinds of friends in terms of intimacy, which can be seen from idiom 18 to idiom 54 .

h)People tend to make friends with whoever is similar to them, as is expressed in idiom 55 .

\section{Contrastive Analysis}

English idioms express the notion that true friends are precious, and fair-weather friends are despised, but even true friends do not have to go through thick and thin with each other or help each other voluntarily. Besides, the quality instead of quantity of friends is emphasized. Friends always share with one another. In contrast, in Chinese idioms, loyalty and faithfulness between friends are very important. So, true friends are those who can company them through thick and thin without condition. Besides, friends should help each other regardless right or wrong, even sacrifice for one another. According to Jia Yuxin, people should show concern, sympathy, and empathy for or offer help to those who are in trouble. "In reality, the relationship in Chinese society is reciprocally obligatory, so everybody in the Chinese society is, to different degrees, indebted to other people, who are in turn also indebted." (Jia, Y, 1999, 505)

Chinese idioms show that friends attach much emphasis to emotional and spiritual closeness as well as physical intimacy. Huang, Y. makes a contrastive analysis of the different friendship view between the Chinese and the American, and notes that friends in China are more familiar with one another in terms of family background, educational background, interests, and even private life than the friends in America. This is true between friendships in Chinese and English cultures. Besides, Chinese people make friends based on common interests and emotional purpose while people in English culture make friends based on profit or instrumental purpose. Just as Jia (1999) notes, "Chinese people regard the maintenance of interactional closeness based on good feeling or expressive relationship between people as an end, while the westerners regard interactions as a means or instrument to anther goal." (Jia, Y, 1999, 515)

Due to the intimacy between friends the influence of friends is emphasized. Concerning the importance of the influence of friends, Chinese idioms propose some suggestions for making friends. However, in English idioms, the author does not find any idioms expressing that idea.

Both English and Chinese idioms show that there is a tendency for people to make friends with whoever is similar to them. And friends are classified into different types according to the degree of intimacy. As it is noted, "human relationships are hierarchical". (Chen \& Starosta, 2007, 113) Different levels of relationships include strangers, acquaintances, intimate friends, and each asks for different engagement in terms of inclusion, control and affection.

\section{Long-term versus Short-term Orientation}

Generally speaking, in long term oriented societies, people value actions and attitudes that affect the future, such as persistence, thrift, and a sense of shame. In short-term oriented societies, people value actions and attitudes that are affected by the past or the present, such as immediate stability, protecting one's own face, respect for tradition, and reciprocation of greetings, favors, and gifts.

Analysis of Samples from English Idioms 
Here are the English idioms about long-term versus short-term orientation collected by the author:

1. Friendship cannot stand always on one side

2. If you scratch my back, I will scratch yours.

3. Claw me and I will claw thee.

4. Roll my log and I will roll yours.

5. Get on/along like a house on fire

6. Old friends and old wine are best

7. (Even) the best of friends must part.

8. Friends may meet but mountains never greet.

9. Friends are thieves of time

After the English idioms listed above, it is appropriate to conclude that the friendship view in English-speaking countries has the following characteristics:

a) Friendship is a matter of reciprocation, as is show in idiom 61. People treat their friend in the same way as their friends treat them. If a friend of someone does him a favor, he will repay his friend with a favor, as can be seen from idiom 62, 63, and 64 .

b) Good friendship may develop very fast. For example, as in idiom 65, if two people get on like a house on fire, they quickly become intimate friends.

c) Old friends are desired and regarded as the most precious, which can be seen from idiom 66.

d) It is natural and common for friends to part and meet. People accept this fact easily so they may part with a friend today and develop another friendship tomorrow, or expect to meet again with old friends in a few days. This point shows itself in idiom 67 and 68.

e) There is an idiom expressing the idea that making friends may take a lot of your time, as is shown in idiom 69 .

\section{Analysis of Samples from Chinese Idioms}

With the above-mentioned idioms in mind, it is reasonable do summarize the features of friendship view reflected in Chinese idioms as follow:

1. yǒuyì cháng cún friendship long exist

Friendship lasts forever.

2. bù wàng jiǔ yào not forget long friend

Do not forget the old friends.

3. duō nián dē péngyǒu——ăo jiāoqing many year of friend---old relationship friendship of a long time means deep relationship

4. zhāo qín mù chǔ morning Qin-state dust Chu-state to change one's loyalty constantly

5. lǒng jiăo zhī jiāo coil bun of relationship Friends from childhood

6. liăng xiăo wú cāi two small no suspicion (of a boy and a girl) be innocent playmates

7. lǐ shàng wănglái courtesy call-for reciprocity

Courtesy demands reciprocity.

8. tóu táo bào lǐ throw peach return plum to return the compliment

9. sòng jūn qiān lǐ, zhōng xū yī bié. send you thouand li finally must one departure Friends must apart even if they do not want to.

10. yī jiàn rú gù one meeting like old-friend to feel like old friends at the first meeting

a) long-term friendship is desired. Idiom 70 expresses the notion that it is important to maintain friendship for as long as possible. People may make new friends, but should never forget the old ones, as is conveyed in idiom 71 . Old friends usually have deep affection, thus are desirable, as can be seen in idiom 72. On the contrary, people are criticized if they change friends constantly or make friends with a person, later abandon that friends and make friends with another 
person. Idiom 73 conveys this idea. In addition, friendship that begins from childhood usually means intimacy and closeness, thus it is desired. This point manifests itself in idiom 74 and 75 .

b) Friendship is a matter of reciprocation. If a person receives gifts or favors from his friends, he should pay his friends back with something in accord with the received things, or even with more valuable things. Idiom 76 and 77 convey this idea.

c) When friends have to part, they express the feeling that they do not want to part and going to miss each other very much, as is seen from idiom 78

d) People may become friends quickly, which can be seen from idiom 79. On the other hand, people compare those quickly-made friends to old friends: they become in good terms quickly as if they were old friends. So it is fair to infer that quickly-made friends are usually not well-regarded except that they are like old friends.

\section{Contrastive Analysis}

English idioms reflect that old friends are good, but quickly-made friends are not necessarily bad. As a matter of fact, old and new friends can both be good or bad. It is naturally accepted that friends may part and meet again, so people just take that easily. According to $\mathrm{Hu}$ (1999), western people tend to move more frequently than Chinese people, therefore their friends also change more frequently than Chinese people. In contrast, old friends are valued in Chinese idioms under any circumstances and new friends are rarely regarded as good as old friends. Just as Hu (1999) notes, the longer time friends know each other, the deeper their relationship will be. Huang (2008) points out that the friendship in China is very stable, even last for a lifetime. Therefore, people are sentimental when they have to part with their friends.

The same idea that is expressed in both English and Chinese idioms is that people should treat their friends the way their friends treat them, or even better. This idea is also expressed as "human relationships are reciprocal". (Chen \& Starosta, 2007, 113). This reciprocation fosters ever-lasting good interpersonal relationship in China, and smooth and balanced short-term relationship in English countries. Only if each member of the relationship satisfies one another's needs of inclusion, control and affection to a certain degree, can the relationship last long. Therefore, if a person received a favor or gift from his friend, he should repay his friend so that their friendship can last for a long time.

Generally speaking, long-term friendship dominates China, where people live in a certain area, which is less likely to change, and interact with a certain group of people. Long-term relationship fosters a complementary social reciprocity in which interpersonal relationship is viewed as asymmetrical and reciprocally obligatory, as is mentioned in the previous two sections. Therefore, Chinese people value stable and long-term relationship, and measure the depth of relationship with the length of time. They maintain the relationship by vertical social status and mutual obligation. While in the English culture, short-term relationship is more prevalent. People tend to move from one place to another, and interact with different people because of the movement as well as their membership of different groups. They consider commitments or obligations between friends as a threat to freedom. Thus short-term relationship is common and popular in English culture.

\section{Cultural Origins of the Two Different Friendship Views}

The differences of friendship views are the result of different cultural, social, social, psychological and natural geographical factors, of which the most important is cultural factor. Individualism, the dominant orientation in English countries and collectivism, the dominant orientation in China act as shapers of the patterns of interpersonal relationships. As the main cultural orientation in the English countries and China are different, the interpersonal relationships are also markedly different.

What is emphasized in English culture is individualism and as a result equal or horizontal relationship is highly valued. Broadly speaking, individualism refers to the doctrine that each individual is unique, special, and completely different from other individuals. Most westerners believe that each person has his own separate identity and personality, which should be recognized and reinforced. People in English culture emphasize individualism so much that they believe that there must be something wrong with people who fail to demonstrate individualism. As a result, they are independent and value privacy. The relationships are symmetrical in English culture in that the behavior which is appropriate to one person in each pair is identical with what is appropriate to the other person. This symmetry presupposes role equality rather than differentiation as is the case in China.

To Chinese people, the word"individualism"is related to the derogatory meaning of egoism, which represents selfishness in quality and looseness in discipline. In traditional Chinese beliefs, especially in Confucianism, collectivism is appreciated. It emphasizes cooperation among group members and individual success is due to the collective effort of the staff in a unit, an organization or a community. So people are generally dependent on each other and have less privacy that the westerners. The sacrifice of individual interest for that of the collective is a noble quality highly praised by Chinese people.

June Ock Yum studied interpersonal relationships through analyzing cultural orientations in the East and West. Yum also agrees that collectivism, especially Confucianism, and individualism are the cardinal principles of their respective interpersonal relationships. Through analyzing the cultural orientations of the East and the West, Yum got his own conclusions:

a) Interpersonal relationship in the East is particularistic while in the West it is universalistic.

b) The eastern interpersonal relationship is long-term and asymmetrical, while the western is short-term and 
symmetrical or contractual.

c) In the East, there is clear distinction between in-group and out-group, while in the West there is not.

\section{CONCLUSION}

The main purpose of this paper is to make a contrastive analysis of the friendship views in Chinese and English idioms. First, there are some differences in friendship views reflected in English and Chinese idioms. Influenced by Confucianism, Chinese people pay much attention to the harmonious relationship based on vertical social status, collectivist reciprocal obligation and emotional feeling, as a result of which long-term and stable relationship is desired. The English idioms show that people are influenced by the doctrine of individualism deeply. As a result, the "autonomous self" based on equality, freedom and instrumentality is emphasized in interpersonal relationship. So the relationship is usually unstable and changing between people. Second, some ideas are common to people in China and English-speaking countries. People from both China and English-speaking countries think they should treat their friends the way their friends treat them. Both English and Chinese idioms show that there is a tendency for people to make friends with whoever is similar to them. And friends are classified into different types according to the degree of intimacy.

By doing this research, the author hopes to contribute a little in both theoretical and practical ways. Theoretically, this paper provides people with friendship views in China and the English-speaking countries from the perspective of idiom, which can enrich the theories proposed by domestic and foreign scholars. Practically, the paper can offer a guideline for interpersonal interactions in China or the English-speaking countries. With a better understanding of the similarities and differences of friendship views in two cultures, people can behave and communicate more properly in intercultural communication.

\section{REFERENCES}

[1] Chen, G and Starosta, W. (2007). Foundations of Intercultural Communication. Shanghai: Shanghai Foreign Language Education Press.

[2] Cook, K. S and Emerson, R. M. (1978). Power, Equity and Commitment in Exchange Networks. New York: John Wiley \& Sons.

[3] Gudykunst, W. \& Kim, Y. (1997). Communicating with Strangers: An Approach to Intercultural Communication. New York: McGraw-Hill.

[4] Hofstede, G. (1991). Cultures and Organizations: Software of the Mind. London: McGraw-Hill.

[5] Hofstede, G. (2001). Culture's Consequences. London: Sage Publications, Inc.

[6] Hofstede, G., \& Bond, M. (1984). Hofstede's Culture Dimensions: An Independent Validationusing Rokeach's Value Survey. Journal of Cross-Cultural Psychology, 15, 417-433.

[7] Homans, G. C. (1958). Social Behavior as Exchange. The American Journal of Sociology. Chicago: The University of Chicago Press.

[8] Hu, W. (1999). Introduction to Intercultural Communication. Beijing: Foreign Language Teaching and Research Press.

[9] Huang Guangguo. (2013) Face and Favor: Chinese Power Game. The American Journal of Sociology. The University of Chicago Press. Vol (92) 944-974.

[10] Huang, Y. (2008). A Contrastive Analysis of Views on Friendship of China and U.S.A. Journal of Nantong Vocational \& Technical Shipping College, 7(3),31-33

[11] Jia, Y. (1997). Intercultural Communication Study (in Chinese). Shanghai: Foreign Language Education Press.

[12] Jia, Y. (1999). Interpersonal Relationship and Intercultural Communication: East and West. In Hu, W.(Eds.), Aspects of Intercultural Communication--Proceedings of China's Second Conference on Intercultural Communication, 505-522. Beijing: Foreign Language Teaching and Research Press.

[13] Lian, Z. (2006). A Research on Interactional Relationship in Intercultural Communication, Dissertation, Yanshan University.

[14] Luo, M. (2006). A Contrastive Study of Traditional Chinese and Western Face and Face-work. Dissertation, Yanshan University.

[15] Samovar, L. Porter, R. \& Stefani, L. (2000). Communication between Cultures. Beijing: Foreign Language Teaching and Research Press.

[16] Stewart, E. C. \& Bennett, M. J. (1991). American Cultural Patterns: a Cross-cultural Perspective. NY: Intercultural press Inc.

[17] Tajfel, H. (1978). Differentiation between Social Groups: Studies in the Social Psychology of Intergroup Relations. London: Academic Press.

[18] Tong, Xiuwen. (2010). On the Value-oriented Discrepancy of Interpersonal Relations between China and West from the Angle of Chinese and English Proverbs. Journal of Zunyi Normal College, 12(6),54-63

[19] Yum, J.O. (2000). The Impact of Confucianism on Interpersonal Relationships and Communication Patterns in East Asia. Communication Monographs. California: Wadworth Publishing Company.

[20] Yum, J. O. (1988). Communication Patterns in East Asia. Communication Monographs. California: Wadworth Publishing Company. 
Qian Zhang was born in Baoding, Hebei Province, China in 1976. She received her M.A. degree in English Language and literature from Hebei University, China in 2009. She is currently a lecturer in Foreign Language department of Baoding University, Hebei, China. Her research interests include British \&American Literature and Foreign Language Teaching.

Xiufeng Tian was born in Hebei Province, China in 1980. She received her Master's degree in English language and literature from Hebei University, China in 2009. In 2012, she received her Master's diploma from Nanyang Technological University. Currently she is a lecturer in the Foreign Language Department, Hebei Finance University, China. Her research interests include second language acquisition, and teaching English as a foreign language. 